\title{
Rancang Bangun Sistem Informasi Manajemen Proyek Berbasis Web Pada PT Seatech Infosys
}

\author{
Doni Darmawan ${ }^{[1]^{*}}$, Anita Ratnasari[ ${ }^{[2]}$ \\ Program Studi Sistem Informasi ${ }^{[1], ~[2] ~}$ \\ Universitas Mercu Buana ${ }^{[1],[2]}$ \\ Jakarta, Indonesia \\ e-mail: 41816110204@student.mercubuana.ac.id ${ }^{[1]}$, anita.ratnasari@mercubuana.ac.id ${ }^{[2]}$
}

\begin{abstract}
Every company engaged in IT Consulting is in need of an application that can help management control the projects they work on. This study examines the problems that occur when a company works on a project, aimed at analyzing the effectiveness of the application of project management applications in order to assist the company in presenting information about the project being undertaken or information officers and clients. The study used case studies at PT. Seatech Infosys Considering systems that still use simple data processing tools such as Microsoft Excel, ranging from data logging, data storage to report generation. Thus, it is possible to have errors in recording and less accurate reports are made. The development of the system with the method used is waterfall method. The result of this analysis is to declare that this application is one solution to overcome existing problems, to achieve an effective and efficient activities in supporting the project activities.
\end{abstract}

Keywords-Web base Application, Project Management, Information System

Abstrak- Setiap perusahaan yang bergerak di bidang konsultan IT sangat membutuhkan aplikasi yang dapat membantu manajemen melakukan kontrol terhadap proyekproyek yang dikerjakan. Penelitian ini mengkaji permasalahan yang terjadi ketika sebuah perusahaan mengerjakan sebuah proyek, yang bertujuan untuk menganalisis efektivitas penerapan aplikasi manajemen proyek dalam rangka membantu perusahaan dalam menyajikan informasi mengenai proyek yang sedang dikerjakan ataupun informasi petugas dan klien. Penelitian ini menggunakan studi kasus pada PT. Seatech Infosys mengingat sistem yang masih menggunakan alat pengolahan data yang sederhana seperti Microsoft Excel, mulai dari pencatatan data, penyimpanan data sampai dengan pembuatan laporan. Sehingga memungkinkan terjadinya kesalahan dalam pencatatan serta kurang akuratnya laporan yang dibuat. Pembangunan dari sistem tersebut dengan metode yang digunakan adalah metode waterfall. Hasil dari analisis ini yaitu menyatakan bahwa aplikasi ini merupakan salah satu solusi untuk mengatasi permasalahan-permasalahan yang ada, agar tercapainya suatu kegiatan yang efektif dan efisien dalam menunjang aktifitas proyek.

Kata Kunci-Aplikasi berbasis web, manajemen proyek, sistem informasi

\section{PENDAHULUAN}

Teknologi Informasi merubah sesuatu dengan cepat.
Teknologi informasi yang merupakan perpaduan antara teknologi komputer dan telekomunikasi, mengganti paradigma industrial menjadi paradigma post-industrial yang berarti juga merubah perilaku lingkungan bisnis atau pebisnis, yang berarti bahwa teknologi informasi memperoleh kedekatan antara pebisnis dengan pelanggannya, karena ini mempersingkat jarak dan waktu sehingga akan mengurangi kesenjangan jarak dan waktu permintaan konsumen dan pemenuhan kebutuhannya. Dengan adanya perubahan dalam lingkungan bisnis ini, akan menyebabkan perubahan dalam bentuk pengambilan keputusan manajemen yang berarti bahwa struktur organisasi dengan adanya teknologi informasi ini menuntut suatu struktur yang cepat terbentuk dan terbentuk kembali sebagai akibat adanya perubahan yang cepat [1]. Salah satunya yaitu dalam memanajemen proyek.

Menurut Mahmoudi dan Feylizadeh berdasarkan Project Management Body of Knowledge, terdapat 6 buah konstrain dalam sebuah proyek, yaitu waktu (time), biaya (cost), ruang lingkup (scope), kualitas (quality), sumber daya (resource), dan resiko (risk). Satu atau lebih dari konstrain dalam proyek dapat memiliki beban atau nilai yang lebih besar dari konstrain lainnya, dan seorang manajer proyek harus dapat menyeimbangkan konstrain-konstrain tersebut dengan cara yang dapat mencapai semua tujuan dari proyek [2].

Manajemen proyek adalah suatu proses pengolahan proyek yang meliputi perencanaan, pengorganisasian dan pengaturan tugas-tugas sumber daya untuk mewujudkan tujuan yang ingin dicapai, dengan mempertimbangkan faktor-faktor waktu dan biaya [3]. Manajemen proyek dapat diterapkan pada jenis proyek apapun, dan dipakai secara luas untuk dalam menyelesaikan proyek yang besar dan kompleks. Fokus utama manajemen proyek adalah pencapaian semua tujuan akhir proyek dengan segala batasan yang ada, waktu dan dana yang tersedia.

Monitoring merupakan kegiatan pemantauan yang dapat dijelaskan sebagai kesadaran (awareness) tentang apa yang ingin diketahui. Pemantauan berkadar tingkat tinggi dilakukan agar dapat membuat pengukuran melalui waktu yang menunjukkan pergerakan ke arah tujuan atau menjauh dari tujuan itu. Monitoring bertujuan untuk mengkaji apakah kegiatan-kegiatan yang dilaksanakan telah sesuai dengan rencana, mengidentifikasi masalah yang timbul agar langsung 
dapat diatasi, melakukan penilaian apakah pola kerja dan manajemen yang digunakan sudah tepat untuk mencapai tujuan, mengetahui kaitan antara kegiatan dengan tujuan untuk memperoleh ukuran kemajuan [4].

Seiring berkembangnya teknologi informasi, manusia mulai menggunakan komputer dalam melakukan manajemen proyek, untuk membantu otomatisasi dan perhitungan. Peralihan manajemen proyek dengan menggunakan komputer membuat manajemen proyek menjadi lebih cepat, efektif dan efisien. Perkembangan perangkat lunak yang pesat juga mendorong transformasi manajemen proyek yang tradisional menjadi sebuah perangkat lunak manajemen proyek. Didalam proses pengerjaan suatu proyek yang sedang berlangsung, akan ada monitoring baik dari pimpinan perusahan maupun dari klien. Semua itu berfungsi untuk manajemen proyek tersebut.

Selama proyek berlangsung, manajer proyek akan mengontrol dan bertanggung jawab serta membagi tugas selama proyek berjalan, lalu membuat laporan kemajuan proyek ke kantor serta untuk keperluan klien. Sebuah perangkat lunak manajemen proyek harus dapat memenuhi kebutuhan-kebutuhan berbagai pengguna. Oleh sebab itu, penulis berkeinginan menganalisis interaksi manusia dan komputer pada perancangan perangkat lunak manajemen proyek agar dapat membuat pekerjaan menjadi lebih produktif, efektif, efisien, aman, dan fungsional. Pekerjaan menjadi lebih mudah diselesaikan dengan interaksi yang baik, sehingga menguntungkan pengguna. Senada dengan itu, rancangan yang tidak sesuai dapat mengakibatkan masalah yang tidak diharapkan, dan pada akhirnya merugikan pengguna.

Penelitian ini mengkaji permasalahan yang terjadi ketika sebuah perusahaan mengerjakan sebuah proyek, yang bertujuan untuk menganalisis efektivitas penerapan aplikasi manajemen proyek dalam rangka membantu perusahaan dalam menyajikan informasi mengenai proyek yang sedang dikerjakan ataupun informasi pegawai dan klien. Penelitian ini menggunakan studi kasus pada PT. Seatech Infosys mengingat sistem yang masih menggunakan alat pengolahan data yang sederhana seperti Microsoft Excel, mulai dari pencatatan data, penyimpanan data sampai dengan pembuatan laporan. Sehingga memungkinkan terjadinya kesalahan dalam pencatatan serta kurang akuratnya laporan yang dibuat. Pembangunan dari sistem tersebut dengan metode yang digunakan adalah metode waterfall serta menganalisis permasalahan menggunakan metode PIECES.

Mengacu pada penelitian sebelumnya [5] lemahnya manajemen proyek yang dilaksanakan dan kurangnya komunikasi dan kolaborasi antara manajer proyek, tim proyek, pemilik proyek, stakeholder, dan semua pihak lain yang terlibat, maka penelitian ini bertujuan untuk membantu perusahaan memilih konsultan IT untuk mengerjakan proyeknya, membantu konsultan IT melakukan manajemen proyek yang terkait dengan proses perancangan, serta pelaksanaan suatu proyek teknologi informasi, dan juga membantu perusahaan untuk melakukan pengawasan perkembangan proyek teknologi informasinya. Penelitian [6] Di PH Masa Creative Yogyakarta terdapat masalah pelaporan kinerja karyawan yang masih dilakukan manual dan belum terstruktur, yang bertujuan memberikan kemudahan bagi manajer dalam mengawasi semua proses proyek yang berjalan, pengontrolan pengerjaan proyek, sinkronisasi antara jadwal dan pengerjaan proyek dan proses pelaporan akhir proyek yang berjalan. Pada penelitian ini kali ini penulis akan mengembangkan penelitian yang dilakukan pada penelitian terdahulu dengan memasukan menu pengadaan barang dan sub menu surat perintah kerja.

Dengan berdasarkan penelitian-penelitan sebelumnya dan hasil studi kasus pada PT. Seatech infosys, penelitian ini diharapkan dapat menghasilkan sebuah sistem manajemen proyek yang sesuai dengan kebutuhan dari hasil studi kasus dengan tetap menjaga kesederhanaan sistem.

\section{LANDASAN TEORI}

\section{A. Definisi Perancangan Aplikasi}

Perancangan merupakan suatu kegiatan yang memiliki tujuan untuk mendesign sistem baru yang dapat menyelesaikan masalah-masalah yang dihadapi perusahaan yang diperoleh dari pemilihan alternatif sistem yang terbaik. Perancangan atau rancang merupakan serangkaian prosedur untuk menterjemahkan hasil analisa dan sebuah sistem ke dalam bahasa pemrograman untuk mendeskripsikan dengan detail bagaimana komponen-komponen sistem di implementasikan [7].

\section{B. Sistem Informasi Manajemen}

Sistem Informasi Manajemen adalah sebuah sistem, yaitu rangkaian terorganisasi dari sejumlah bagian atau komponen yang secara bersama - sama berfungsi atau bergerak menghasilkan informasi untuk digunakan dalam manajemen perusahaan [8].

Keberhasilan suatu organisasi dalam mencapai tujuannya sangat tergantung pada kemampuan orang yang mengelola organisasi tersebut. Manajemen sebagi suatu metode yang mengatur, mengelola organisasi dapat diartikan sebagai seni melaksanakan sesuatu melalui orang. Jika manajemen suatu organisasi baik maka akan meningkatkan kemakmuran suatu negara [9].

Sistem informasi manajemen memiliki banyak manfaat baik bagi pihak manajemen, adapun manfaat sistem informasi manajemen seperti :

1) Meningkatkan efisiensi dan efektivitas data secara akurat dan realtime.

2) Memudahkan pihak manajemen untuk melakukan perencanaan, pengawasan, pengarahan, dan pendelegasian kerja kepada semua departemen yang memiliki hubungan atau koordinasi.

3) Meningkatkan kualitas sumber daya manusia, karena unit sistem kerja yang terkoordinasi dan sistematis.

4) Meningkatkan produktivitas dan penghematan biaya dalam organisasi.

\section{Manajemen Proyek}

Manajemen proyek merupakan strategi yang perlu dilakukan dalam mencapai efisiensi dan efektifitas suatu 
perusahaan, Perencanaan manajemen proyek yang dilakukan untuk menjalankan proyek dengan sebaik mungkin. Manajemen Proyek dibutuhkan untuk dapat meningkatkan keuntungan perusahaan, tetapi disisi lain peningkatan atas permintaan proyek tersebut dapat menjadi masalah dalam perusahaan apabila tidak memiliki manajemen perusahaan yang baik. Manajemen proyek dibuat untuk dapat menghindari atau meminimalisir kegagalan dan resiko proyek. Manajemen yang baik terkait dengan manjemen aktivitas seperti penjadwalan, pengelolaan human resource yang mana akan berujung pada estimasi biaya proyek yang perlu dianggarkan perusahaan [10].

\section{Metode Waterfall}

Metode penelitian yang diterapkan pada penelitian ini adalah dengan pengembangan metode waterfall. Metode waterfall merupakan model pengembangan sistem informasi yang sistematik dan sekuensial [11].

Menurut Pressman model waterfall adalah model klasik yang bersifat sistematis, berurutan dalam membangun perangkat lunak. Pemilihan menggunakan metode ini agar pembuatan aplikasi dapat berjalan secara bertahap dan dapat memenuhi tujuan penelitian. Terdapat 5 tahapan dalam metode waterfall menurut Pressman, akan digambarkan dalam Tahapan Pengembangan dengan Metode Waterfall pada gambar 1.

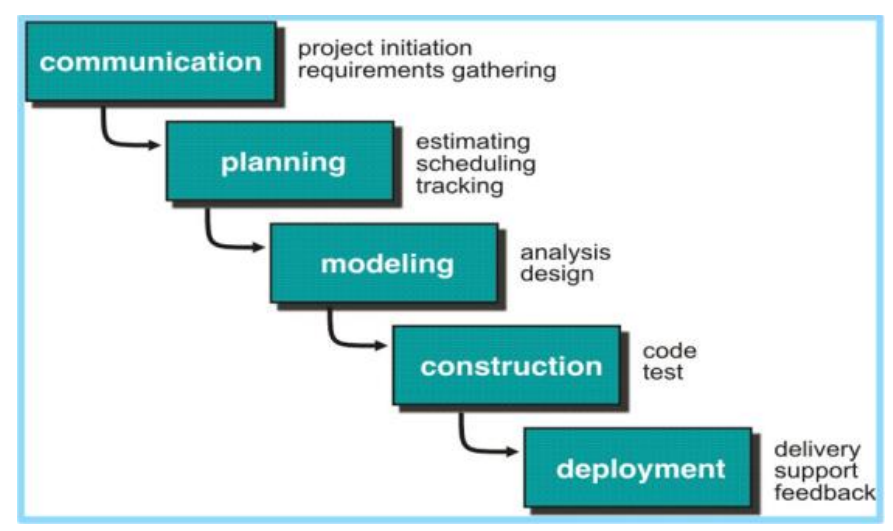

Gambar 1. Tahapan Pengembangan dengan Metode Waterfall (Pressman, 2015)

\section{1) Communication}

Dalam tahapan ini, Sebelum memulai pekerjaan yang bersifat teknis, sangat diperlukan adanya komunikasi dengan user, demi memahami dan mencapai tujuan yang ingin dicapai. Hasil dari komunikasi tersebut adalah inisialisasi proyek, seperti menganalisis permasalahan yang dihadapi dan mengumpulkan data-data yang diperlukan untuk mendukung kebutuhan yang diperlukan aplikasi yang akan dibuat.

\section{2) Planning}

Tahap berikutnya adalah tahapan perencanaan untuk menentukan strategi yang akan diperlukan dalam membangun aplikasi sisthem yang akan dibuat dan melakukan evaluasi dari perencanaan yang akan dilakukan.

3) Modeling
Tahapan ini adalah membuatsebuah rancangan dan pemodelan alur kerja aplikasi yang akan dibuat, baik dari struktur data dan userinterface. Tahapan ini bertujuan untuk membuat dan memahami gambaran besar dari aplikasi yang akan dibuat.

\section{4) Construction}

Tahapan Construction ini merupakan proses bentuk desain yang dibuat sebelumnya diterjemahkan dengan bahasa pemrograman berbasis web. Setelah pengkodean selesai, dilakukan pengujian terhadap sistem dan juga kode yang sudah dibuat dengan metode black box. Tujuannya untuk menemukan kesalahan yang mungkin bisa terjadi agar nantinya dapat diperbaiki.

\section{METODE PENELITIAN}

Metodologi penelitian merupakan suatu perencanaan penelitian yang akan dilakukan secara sistematis dan ilmiah. Pada penelitian ini, dibangun dengan mendesain perencanaan penelitian sehingga mudah untuk dilakukan. Teknik pengumpulan data yang digunakan untuk pengumpulan data yang berkaitan dengan laporan penelitian ini melalui wawancara langsung kepada pihak Project Manager PT. Seatech Infosys dan melakukan observasi langsung serta studi kepustakaan dan studi dokumentasi dari internet. Tahapan proses yang akan dilakukan dalam penelitian ini digambarkan dalam diagram alir pada gambar 2 .

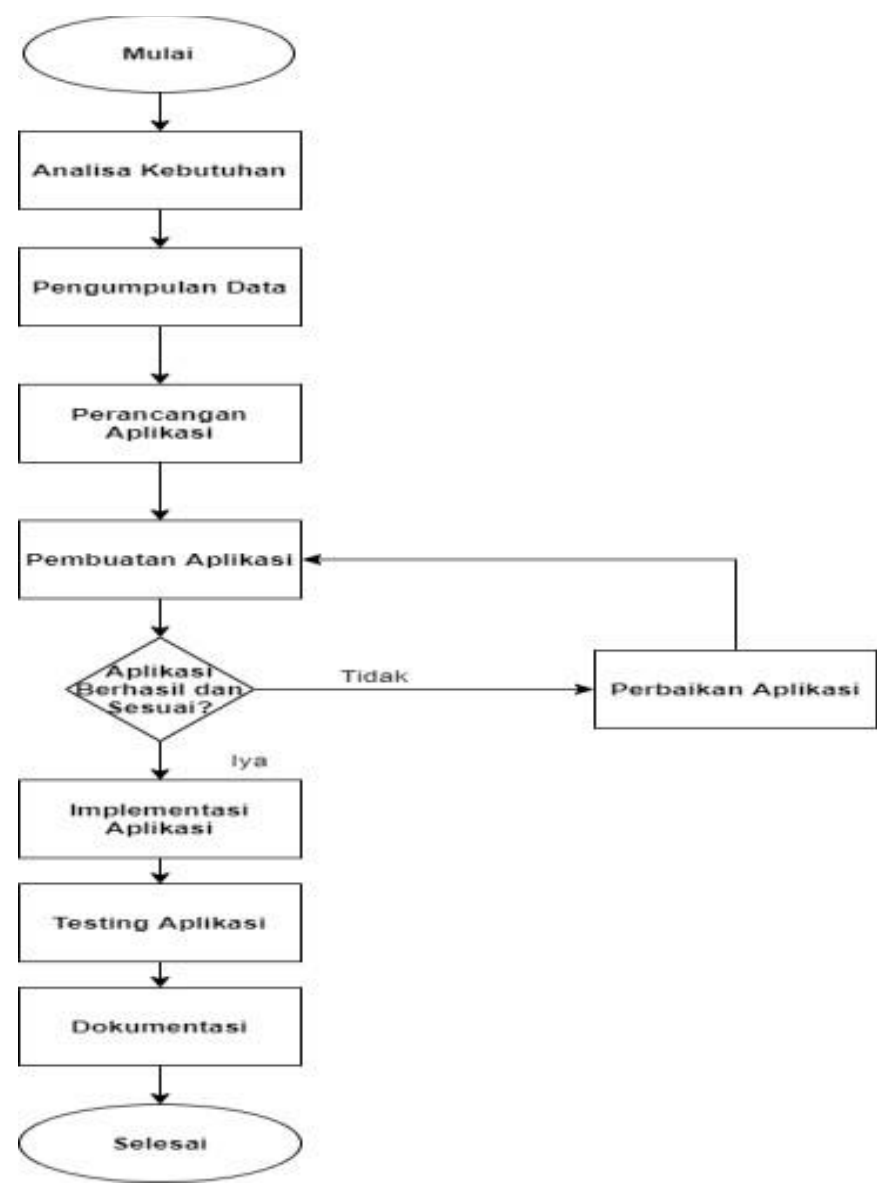

Gambar 2. Diagram Alir Penelitian 


\section{ANALISIS DAN PEMBAHASAN}

\section{A. Analisa Kebutuhan dan Pengumpulan data}

Berdasarkan hasil wawancara dengan Project Manajer PT. Seatech Infosys, observasi secara langsung serta studi kepustakaan dan studi dokumentasi dari internet menghasilkan Sistem Informasi Manajemen Proyek guna menyelesaikan masalah yang terjadi pada PT. Seatech Infosys.

\section{B. Analisa PIECES}

PIECES adalah metode analisis sebagai dasar untuk memperoleh pokok-pokok permasalahan yang lebih spesifik. Dalam menganalisis sebuah sistem, biasanya akan dilakukan terhadap beberapa aspek antara lain adalah kinerja, informasi, ekonomi, keamanan aplikasi, efisiensi dan pelayanan pelanggan. Analisis ini disebut dengan PIECES Analysis (Performance, Information, Economy, Control, Eficiency and Service) [12].

Berikut Pemaparan perbedaan antara sistem lama dengan sistem yang akan diusulkan untuk Manajemen Proyek PT. Seatech Infosys.

\begin{tabular}{|c|c|c|}
\hline Parameter & Kendala & Solusi \\
\hline $\begin{array}{l}\text { Kinerja } \\
\text { (Performa } \\
\text { nce) }\end{array}$ & $\begin{array}{l}\text { a. Pengelolaan data } \\
\text { proyek masih } \\
\text { menginput data masih } \\
\text { manual sehingga } \\
\text { pembagian tugas dan } \\
\text { monitoring proyek } \\
\text { bisa menyebabkan } \\
\text { keterlambatan } \\
\text { pengerjaan proyek. } \\
\text { b. Kesulitan dalam } \\
\text { mengecek proyek } \\
\text { perkembangan sudah } \\
\text { yang dikerjakan sudap } \\
\text { mencapai tahap apa. } \\
\text { c. Penyimpanan data } \\
\text { project masih } \\
\text { menggunakan manual, } \\
\text { sehingga data yang } \\
\text { disimpan tidak punya } \\
\text { backup apabila ada } \\
\text { kehilangan ataupun } \\
\text { kerusakan peralatan } \\
\text { penyimpanan. }\end{array}$ & $\begin{array}{l}\text { a. Setiap penginputan data } \\
\text { proyek yang masuk } \\
\text { mulai dari pembagian } \\
\text { tugas dan monitoring } \\
\text { proyek dapat diinput } \\
\text { kedalam sistem yang } \\
\text { nantinya } \\
\text { diinstruksikan kebagian } \\
\text { staff untuk di tindak } \\
\text { lanjuti. } \\
\text { bata hasil tindak lanjut } \\
\text { akan diinputkan kedalam } \\
\text { sistem untuk mengetahui } \\
\text { perkembangan dari } \\
\text { proyek yang dikerjakan. } \\
\text { Penyimpanan data } \\
\text { project menggunakan } \\
\text { database, sehingga } \\
\text { apabila kehilangan data } \\
\text { berupa hardcopy, } \\
\text { perusahaan masih } \\
\text { memiliki backup data } \\
\text { yang tersimpan di dalam } \\
\text { database. r a }\end{array}$ \\
\hline $\begin{array}{l}\text { Informasi } \\
\text { (Informatio } \\
n \text { ) }\end{array}$ & 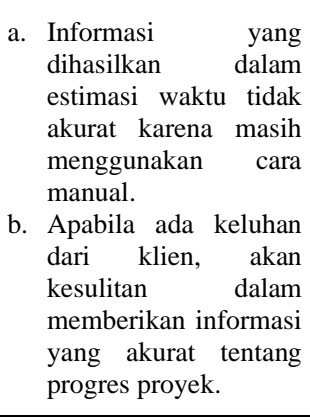 & 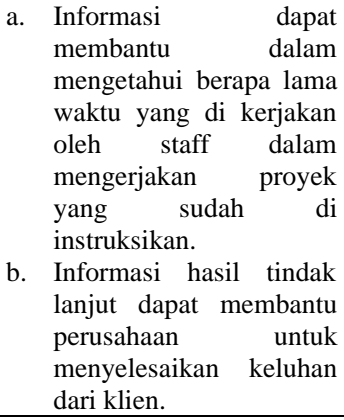 \\
\hline $\begin{array}{l}\text { Ekonomi } \\
\text { (Economy) }\end{array}$ & $\begin{array}{l}\text { a. Sistem lama } \\
\text { membutuhkan banyak } \\
\text { biaya operasional } \\
\text { yang sebenarnya dapat } \\
\text { diminimalisasi, }\end{array}$ & $\begin{array}{l}\text { a. Dengan adanya sistem } \\
\text { yang semua datanya } \\
\text { tersimpan didatabase } \\
\text { sehingga tidak perlu } \\
\text { terjadi banyaknya biaya }\end{array}$ \\
\hline
\end{tabular}

\begin{tabular}{|c|c|c|}
\hline Parameter & Kendala & Solusi \\
\hline & $\begin{array}{lr}\text { diantaranya } & \text { kertas- } \\
\text { kertas arsip } & \text { yang } \\
\text { jumlahnya } & \text { tidak } \\
\text { sedikit, r tempat } & \text { data } \\
\text { penyimpanan } & \text { yang cukup besar, dan } \\
\text { besarnya kebutuhan } \\
\text { tenaga pengelola baik } \\
\text { dalam hal administrasi } \\
\text { maupun akomodasi. }\end{array}$ & $\begin{array}{l}\text { pencetakan dokumen } \\
\text { fisik }\end{array}$ \\
\hline $\begin{array}{l}\text { Kontrol } \\
(\text { Control })\end{array}$ & 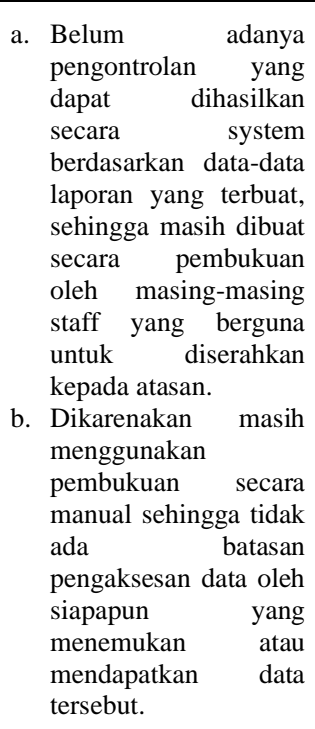 & $\begin{array}{l}\text { a. Laporan yang masuk } \\
\text { kedalam sistem akan } \\
\text { dapat dikontrol oleh } \\
\text { atasan dengan hak akses, } \\
\text { sehingga dari data-data } \\
\text { laporan akan dapat } \\
\text { dilihat oleh atasan. } \\
\text { b. Adanya menu login } \\
\text { membuat staf yang tidak } \\
\text { bersangkutan tidak dapat } \\
\text { mengakses fitur aplikasi } \\
\text { dan data-data penting } \\
\text { perusahaan. }\end{array}$ \\
\hline $\begin{array}{l}\text { Efisiensi } \\
\text { (Efficiency } \\
\text { ) }\end{array}$ & 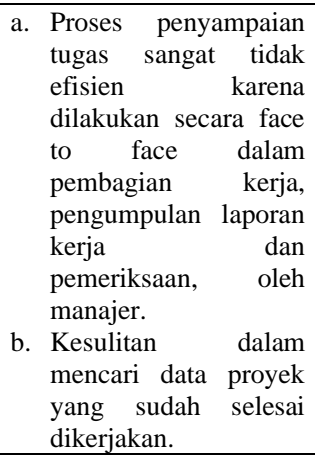 & $\begin{array}{l}\text { a. Sistem membuat segala } \\
\text { data-data pembagian } \\
\text { tugas proyek lebih } \\
\text { efisien. } \\
\text { b. Sistem yang dibuat lebih } \\
\text { efisien sehingga dalam } \\
\text { pembuatan laporan } \\
\text { proyek dan hasil tindak } \\
\text { lanjut dapat lebih mudah. }\end{array}$ \\
\hline $\begin{array}{l}\text { Pelayanan } \\
\text { (Service) }\end{array}$ & 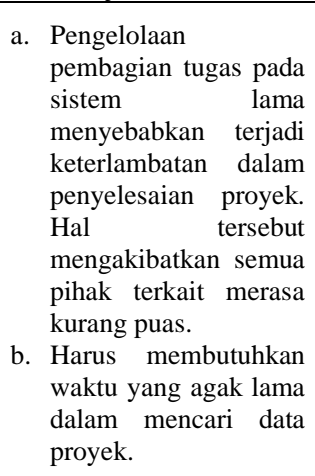 & $\begin{array}{l}\text { a. Sistem yang dibuat dapat } \\
\text { mengurangi } \\
\text { keterlambatan pelayanan } \\
\text { sehingga informasi yang } \\
\text { di dapat lebih diterima. } \\
\text { b. Tidak membutuhkan } \\
\text { waktu yang lama untuk } \\
\text { melakukan pencatatan } \\
\text { dan pencarian data } \\
\text { proyek. }\end{array}$ \\
\hline
\end{tabular}

\section{Perancangan Dan Pembuatan Aplikasi}

Pada tahap ini dalam merancang dan membuat aplikasi berdasarkan data yang di dapat dari hasil analisa kebutuhan 
dan pengumpulan data serta analisa PIECES.

\section{1) Perancangan Aplikasi}

Kegiatan yang dilakukan pada tahap ini yaitu merancang usecase diagram usulan pada gambar 3 dan class diagram pada gambar 4.

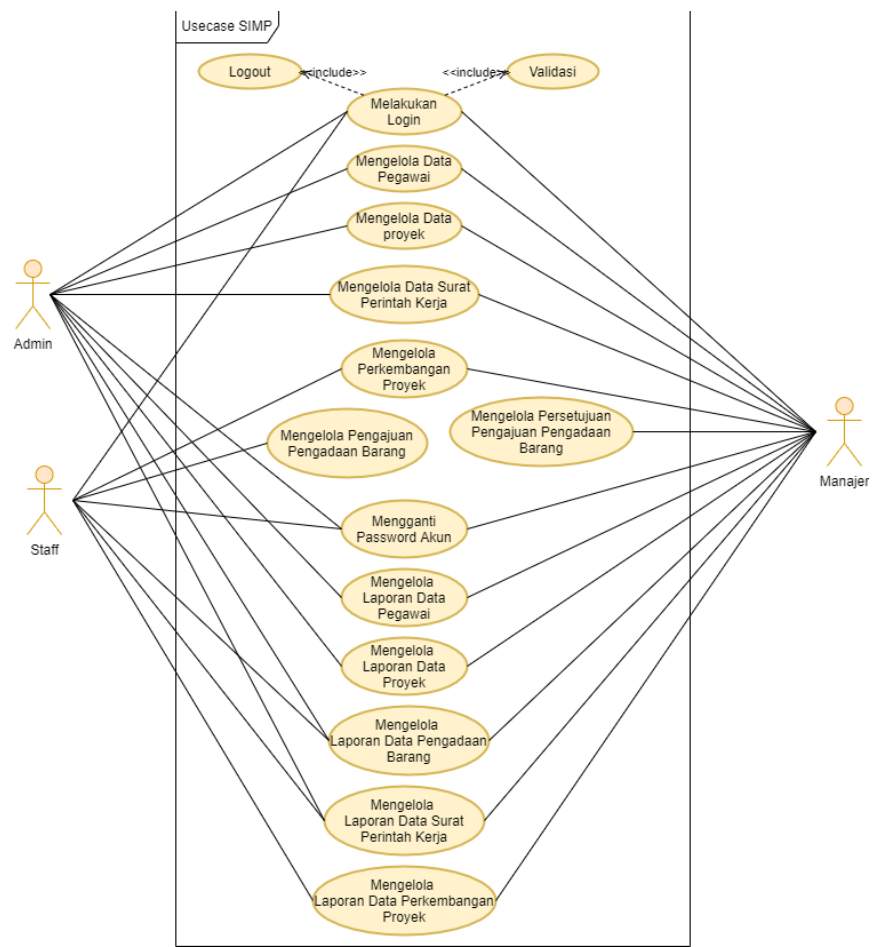

Gambar 3. Usecase Diagram Usulan

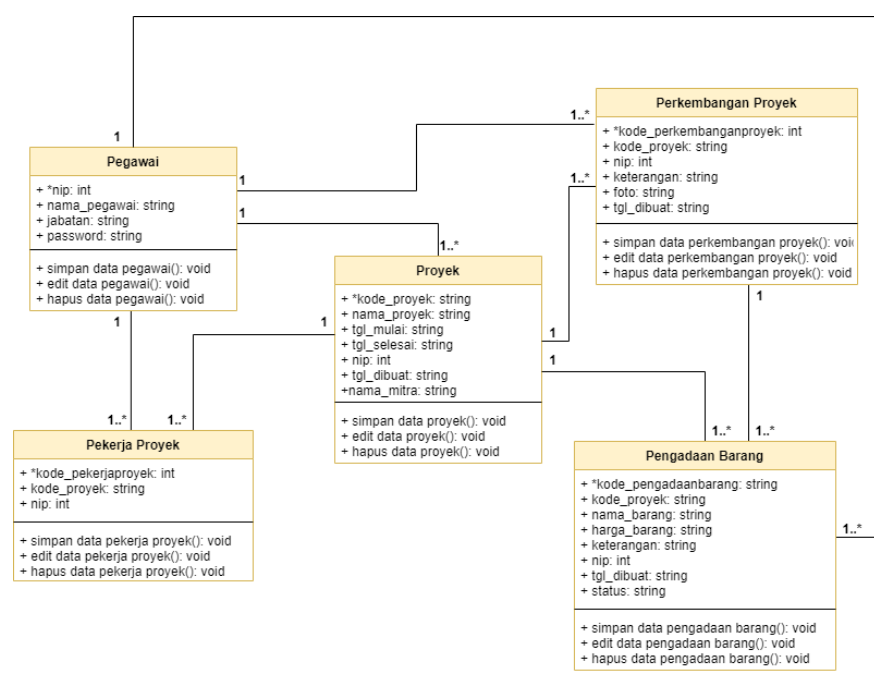

Gambar 4. Class Diagram Usulan

\section{2) Pembahasan Hasil Aplikasi}

Hasil dari penelitian ini merupakan sebuah sistem informasi manajemen proyek berbasis web. Terdapat 3 Aktor pada use case diagram yang di usulkan yaitu Admin, Staff dan Manajer. Semua aktor dapat melakukan aktivitas login dengan memasukan nip dan password. Sedangkan untuk aktivitas lainnya memerlukan hak akses untuk melakukan pengelolaan aktivitas tersebut. Hasil dari penjabaran usecase dilihat dari konsep sistem manajemen proyek dan sistem informasi monitoring maka menghasilkan tampilan antarmuka aplikasi yang terdiri dari tampilan antarmuka sistem dan tampilan laporan sebagai berikut.

\section{3) Implementasi Aplikasi}

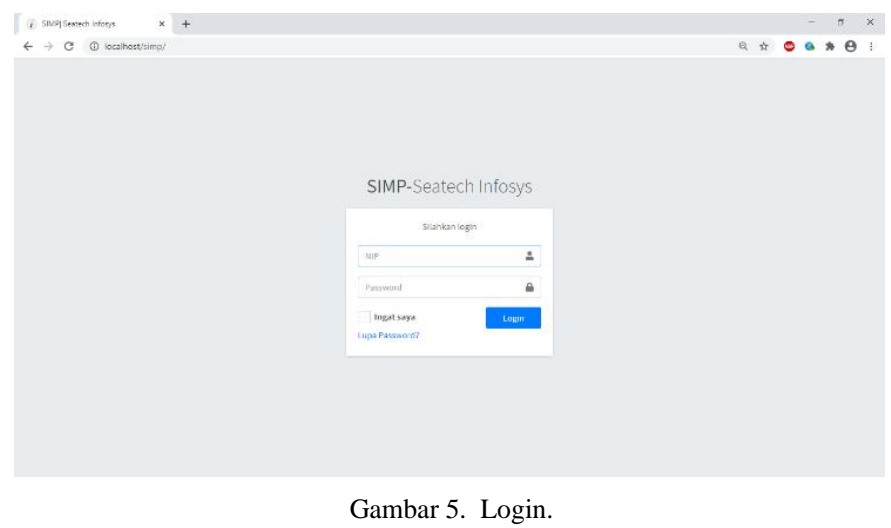

Gambar 5 merupakan halaman login untuk semua pegawai.

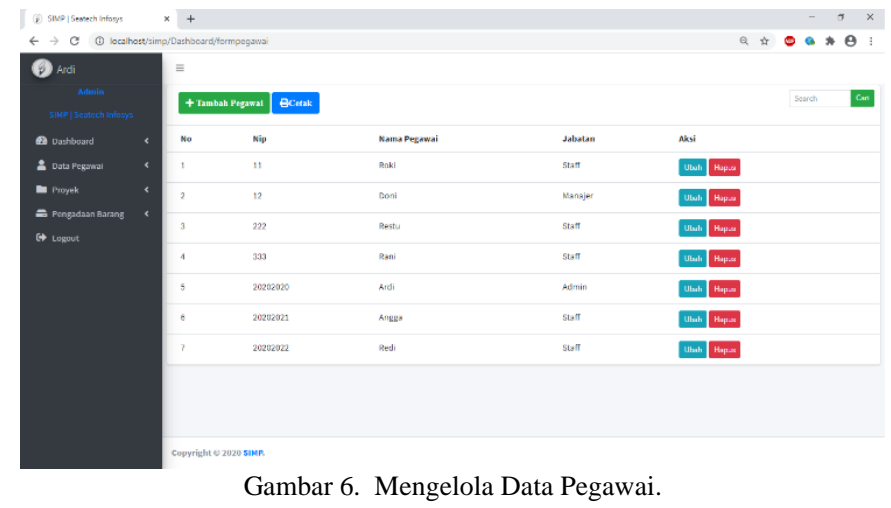

Gambar 6 merupakan halaman mengelola data pegawai, Admin dan Manajer dapat menambahkan, mengubah dan menghapus data pegawai.

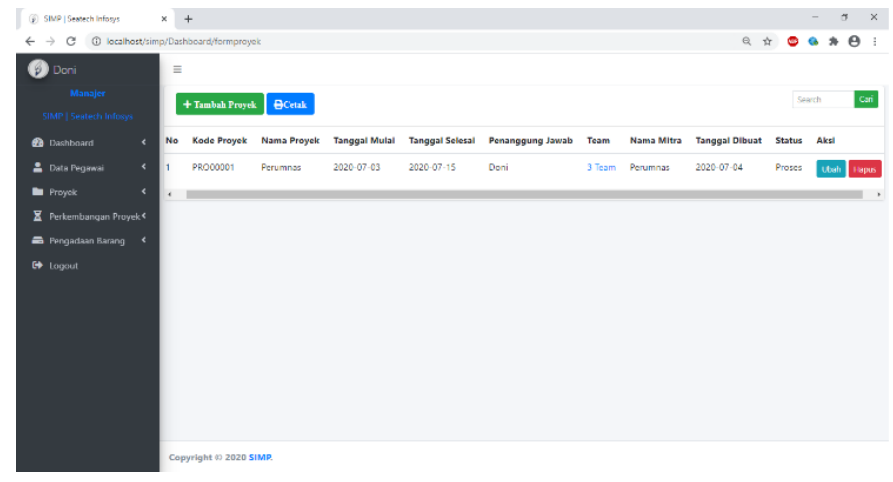

Gambar 7. Mengelola Data Proyek.

Gambar 7 merupakan halaman mengelola data proyek, Admin dan Manajer dapat menambahkan, mengubah dan menghapus data proyek. 


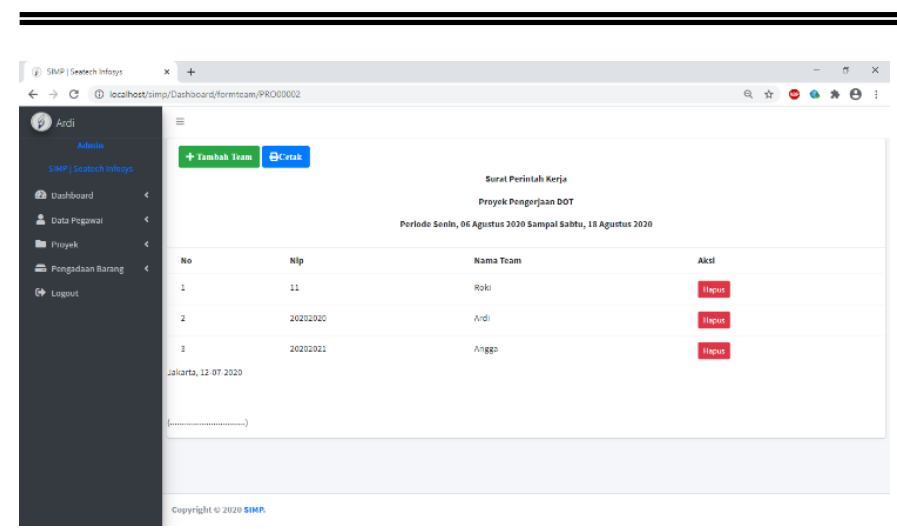

Gambar 8. Mengelola Data Surat Perintah Kerja

Gambar 8 merupakan halaman mengelola data surat perintah kerja, Admin dan Manajer dapat menambahkan dan menghapus data surat perintah kerja.

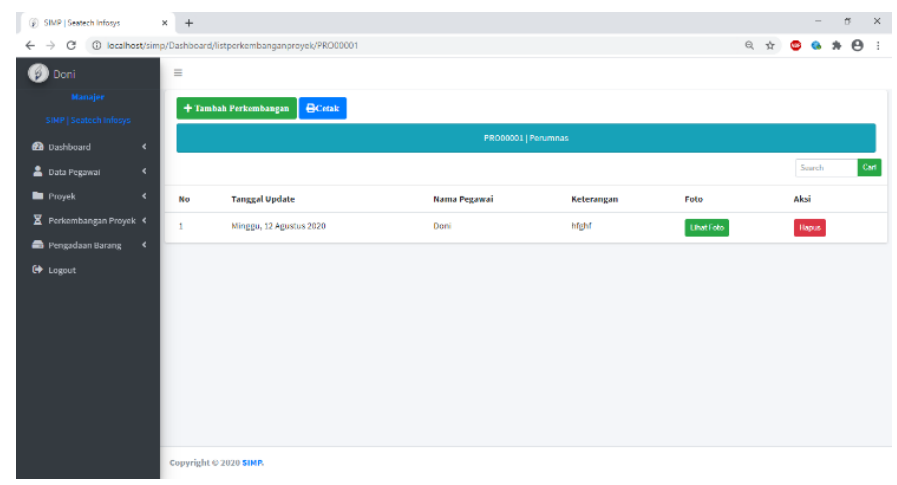

Gambar 9. Mengelola Data Perkembangan Proyek

Gambar 9 merupakan halaman mengelola data perkembangan proyek, Staff dan Manajer dapat menambahkan dan menghapus data perkembangan proyek.

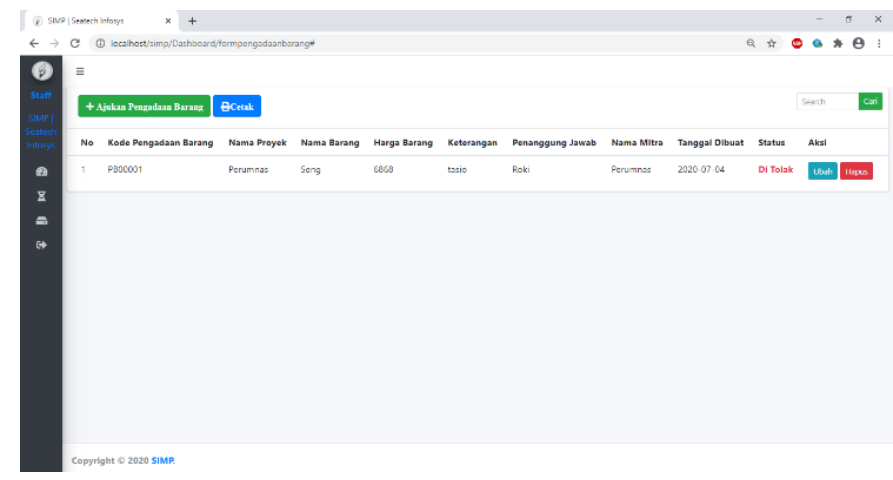

Gambar 10. Mengelola Data Pengajuan Pengadaan Barang

Gambar 10 merupakan halaman mengelola data pengajuan pengadaan barang, Staff dapat menambahkan pengajuan, mengubah dan menghapus data pengajuan pengadaan barang.

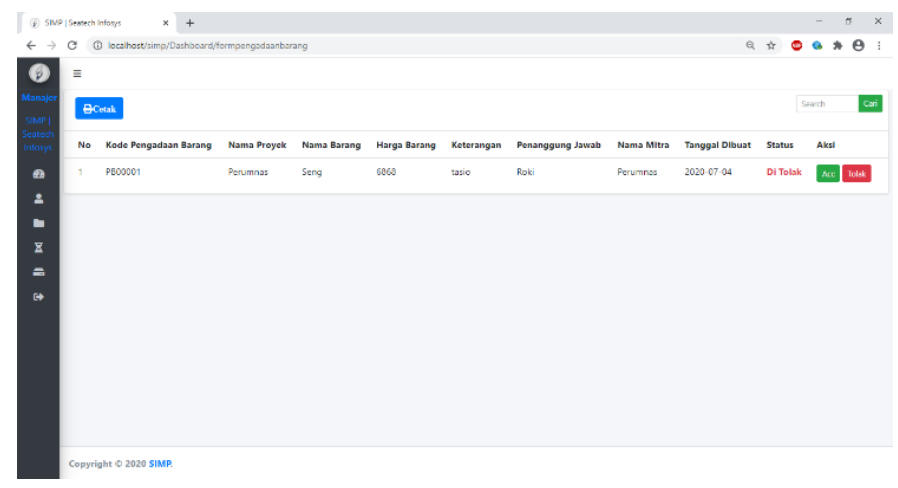

Gambar 11. Mengelola Data Persetujuan Pengadaan Barang

Gambar 11 merupakan halaman mengelola data persetujuan pengadaan barang, Manajer dapat menyetujui atau menolak pengajuan pengadaan barang.

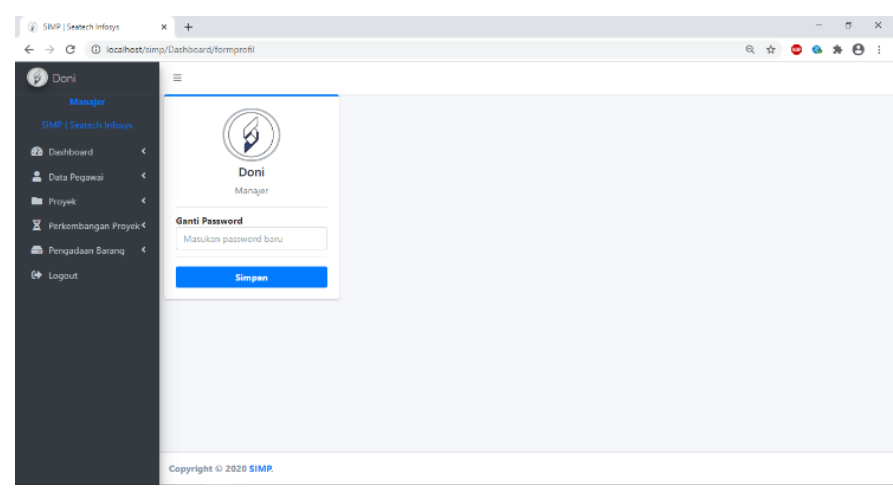

Gambar 12. Mengganti Password Akun

Gambar 12 merupakan halaman mengganti password akun, Admin, Staff dan Manajer dapat menambahkan mengubah atau mengganti password akun masing-masing.

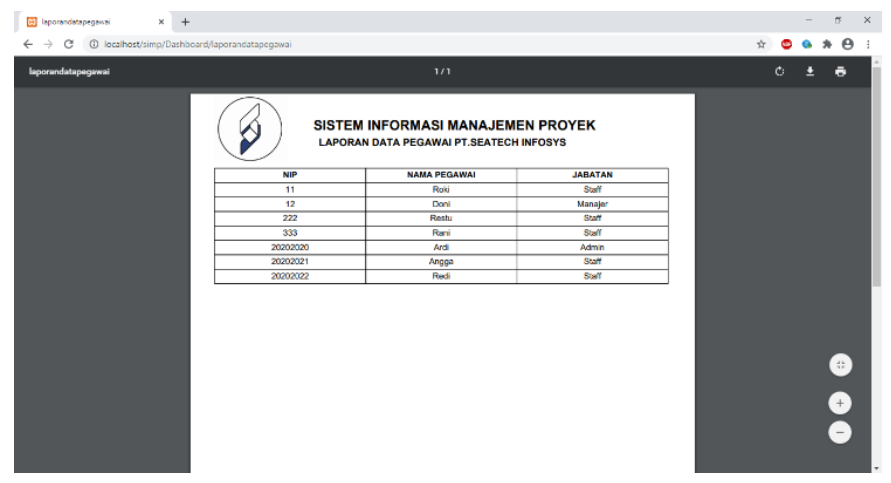

Gambar 13. Mengelola Laporan Data Pegawai

Gambar 13 merupakan halaman mengelola data pegawai, Admin dan Manajer dapat mencetak laporan data pegawai. 


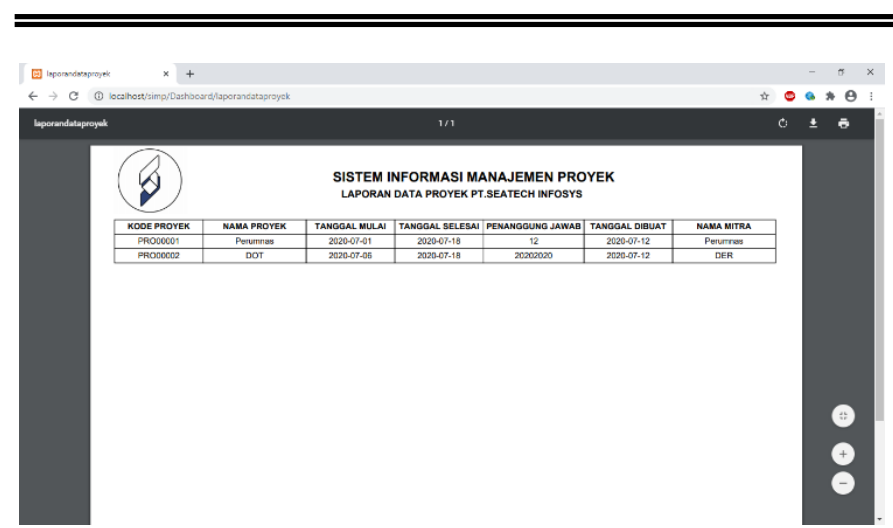

Gambar 14. Mengelola Laporan Data Proyek

Gambar 14 merupakan halaman mengelola laporan data proyek, Admin dan Manajer dapat mencetak laporan data proyek.

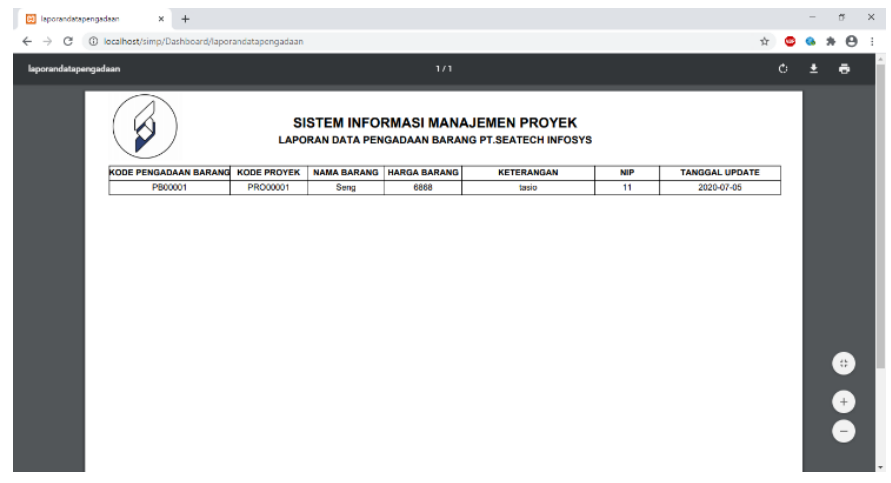

Gambar 15. Mengelola Laporan Data Pengadaan Barang

Gambar 15 merupakan halaman mengelola laporan data pengadaan barang, Admin, Staff dan Manajer dapat mencetak laporan data pengadaan barang.

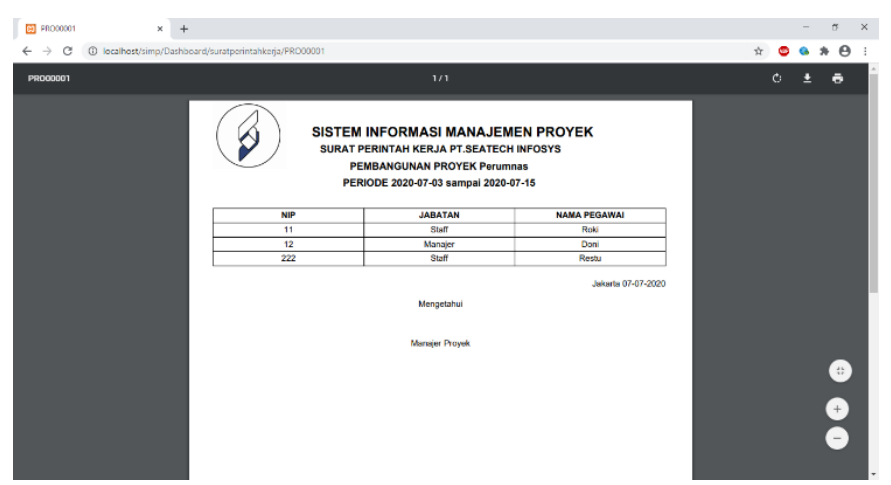

Gambar 16. Mengelola Laporan Data Surat Perintah Kerja

Gambar 16 merupakan halaman mengelola laporan data surat perintah kerja, Admin, Staff dan Manajer dapat mencetak laporan data surat perintah kerja.

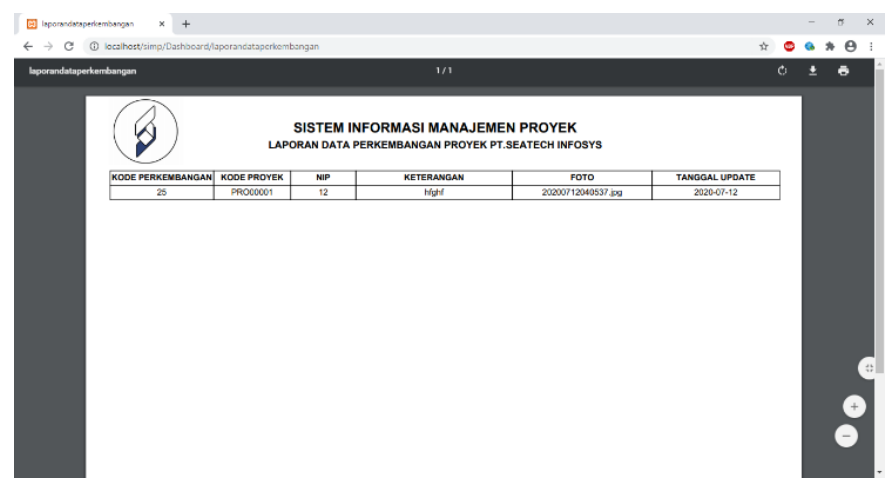

Gambar 17. Mengelola Laporan Data Perkembangan Proyek

Gambar 17 merupakan halaman mengelola laporan data perkembangan proyek, Staff dan Manajer dapat mencetak laporan data perkembangan proyek.

\section{4) Pengujian Aplikasi}

Pengujian aplikasi pada penelitian ini, penulis menggunakan metode pengujian Black box. Black Box Testing berfokus pada spesifikasi fungsional dari perangkat lunak. Tester dapat mendefinisikan kumpulan kondisi input dan melakukan pengetesan pada spesifikasi fungsional program. Pada tabel berikut hanya akan ditampilkan beberapa dari keseluruhan pengujian aplikasi.

TABEL 2. Pengujian Aplikasi

\begin{tabular}{|c|c|c|c|c|c|}
\hline No & $\begin{array}{l}\text { Menu yang } \\
\text { di uji }\end{array}$ & $\begin{array}{l}\text { Item } \\
\text { Pengujian }\end{array}$ & $\begin{array}{l}\text { Cara } \\
\text { Pengujian }\end{array}$ & $\begin{array}{l}\text { Hasil yang } \\
\text { diharapkan }\end{array}$ & \begin{tabular}{|l} 
Hasil \\
Item \\
Pengujian \\
\end{tabular} \\
\hline 1. & Login & Tombol Login & $\begin{array}{l}\text { Masukan Nip } \\
\text { dan password } \\
\text { Tekan tombol } \\
\text { Login }\end{array}$ & $\begin{array}{l}\text { Menampilkan } \\
\text { halaman } \\
\text { menu utama } \\
\text { (dashboard) }\end{array}$ & Berhasil \\
\hline \multirow{6}{*}{2.} & \multirow{6}{*}{$\begin{array}{l}\text { Menu } \\
\text { Utama }\end{array}$} & $\begin{array}{l}\text { Tombol menu } \\
\text { dashboard }\end{array}$ & $\begin{array}{l}\text { Menekan } \\
\text { menu } \\
\text { dashboard }\end{array}$ & $\begin{array}{l}\text { Menampilkan } \\
\text { dashboard }\end{array}$ & Berhasil \\
\hline & & $\begin{array}{l}\text { Tombol menu } \\
\text { data pegawai }\end{array}$ & $\begin{array}{l}\text { Menekan } \\
\text { menu } \\
\text { data pegawai } \\
\end{array}$ & $\begin{array}{l}\text { Menampilkan } \\
\text { list data } \\
\text { pegawai }\end{array}$ & Berhasil \\
\hline & & $\begin{array}{l}\text { Tombol menu } \\
\text { proyek }\end{array}$ & $\begin{array}{l}\text { Menekan } \\
\text { menu proyek }\end{array}$ & $\begin{array}{l}\text { Menampilkan } \\
\text { list proyek }\end{array}$ & Berhasil \\
\hline & & $\begin{array}{l}\text { Tombol menu } \\
\text { perkembangan } \\
\text { proyek }\end{array}$ & $\begin{array}{l}\text { Menekan } \\
\text { menu } \\
\text { perkembangan } \\
\text { proyek }\end{array}$ & $\begin{array}{l}\text { Menampilkan } \\
\text { list } \\
\text { perkembangan } \\
\text { proyek }\end{array}$ & Berhasil \\
\hline & & $\begin{array}{l}\text { Tombol menu } \\
\text { pengadaan } \\
\text { barang }\end{array}$ & $\begin{array}{l}\text { Menekan } \\
\text { menu } \\
\text { pengadaan } \\
\text { barang } \\
\end{array}$ & $\begin{array}{l}\text { Menampilkan } \\
\text { list pengadaan } \\
\text { barang }\end{array}$ & Berhasil \\
\hline & & $\begin{array}{l}\text { Tombol menu } \\
\text { logout }\end{array}$ & $\begin{array}{l}\text { Menekan } \\
\text { menu logout }\end{array}$ & $\begin{array}{l}\text { Menampilkan } \\
\text { halaman login }\end{array}$ & Berhasil \\
\hline
\end{tabular}




\section{KESIMPULAN}

Pengelolaan proyek pada PT. Seatech Infosys saat ini masih dilakukan dengan menggunakan perangkat lunak pengolah data seperti Microsoft Excel, dimana hal ini menjadikan proses pengelolaan proyek terpusat pada satu orang, mempersulit dalam berbagi informasi, dan tidak terstrukturnya berkas antara data satu proyek dengan proyek yang lain. Agar pengelolaan proyek dapat lebih tersturktur, efisien, dan mudah, maka perlu dibangun sebuah sistem manajemen proyek untuk mewadahi setiap proyek. Sistem

Sistem Informasi Manajemen Proyek yang dibangun ini dapat digunakan untuk melakukan pembagian tugas dan monitoring proyek yang sedang di kerjakan oleh PT. Seatech Infosys. Melalui aplikasi ini, manajemen mampu melihat ketersediaan tenaga ahli dan mengawasi perkembangan proyek. Informasi yang dihasilkan pada aplikasi ini selalu up to date dari masing- masing fungsi kerja dan dapat saling berintegrasi sehingga dapat diketahui oleh tim kerja. Aplikasi ini dapat diakses oleh user (pegawai) dengan akun yang sudah terdaftar. Selain itu, dengan menu pengadaan barang, manajer proyek dapat memantau pengeluaran proyek dengan lebih mudah dan dapat mendeteksi pengeluaran yang tidak diperlukan.

Dengan demikian, Sistem Informasi Manajemen Proyek berbasis web yang dikembangkan dan dari hasil pengujian aplikasi menggunakan black box testing telah dapat menyelesaikan permasalahan tidak adanya sistem manajemen proyek pada PT. Seatech Infosys dan juga menyelesaikan permasalahan sulitnya berbagi informasi dan juga membantu manajer proyek dalam pengelolaan proyek dari segi manajemen sumber daya, waktu, dan biaya.

Penelitian ini dibuat berdasarkan data-data yang diperoleh dalam jangka waktu, kondisi, dan pada lokasi tertentu, sehingga terdapat kemungkinan penelitian ini tidak relevan ketika digunakan pada waktu, kondisi, dan lokasi yang berbeda, sehingga disarankan untuk disesuaikan dengan kondisi yang ada.

\section{DAFTAR PUSTAKA}

[1] T. Mildawati, "Teknologi Informasi Dan Perkembangannya Di Indonesia," EKUITAS (Jurnal Ekon. dan Keuangan), vol. 4, no. 2, p. 101, 2016.

[2] A. S. Vidianto and W. H. Haji, "Sistem Informasi Manajemen Proyek Berbasis Kanban ( Studi Kasus: Pt . Xyz ) Kanban Based Project Management Information System ( Case Study: Pt . Xyz )," J. Teknol. Inf. dan Ilmu Komput., vol. 7, no. 2, 2020.

[3] A. Gheffira, Z. M. Inayah, R. Teguh, and D. Oktaviany, "Sistem Informasi Manajemen Proyek Berbasis Website Pada PT. AKM," JATISI (Jurnal Tek. Inform. dan Sist. Informasi), vol. 6, no. 1, pp. 6271, 2019.

[4] J. Juliana, Y. Wibawanti, and M. Haikal, "Monitoring Kemajuan Pengerjaan Proyek Belt Conveyor Plant 14 Hambalang Berbasis Web," Simetris J. Tek. Mesin, Elektro dan Ilmu Komput., vol. 9, no. 1, pp. 2934, 2018.

[5] D. Paramita, "Rancang Bangun Sistem Informasi Kolaboratif Berbasis Web Untuk Manajemen Proyek Teknologi Informasi," J. Buana Inform., vol. 6, no. 3, pp. 195-202, 2015.

[6] B. W. Permana and R. Marco, "Perancangan Sistem informasi Manajemen Proyek Berbasis Website Di PH Masa Creative Yogyakarta," 2016.

[7] A. Fadillah and A. Ratnasari, "Sistem Informasi Penjualan Dan Manajemen Reimburse Pada Perusahaan Distribusi Berbasis Web (Studi Kasus: Pt. Karyatama Maju Berjaya),' J. Cendikia, vol. XVIII, pp. 298 302, 2019.

[8] B. J. Kaleb, V. P. . Lengkong, and R. N. Taroreh, "Penerapan Sistem Informasi Manajemen Dan Pengawasannya Di Kantor Pelayanan Pajak Pratama Manado," J. EMBA J. Ris. Ekon. Manajemen, Bisnis dan Akunt., vol. 7, no. 1, pp. 781-790, 2019.

[9] C. Purnama, "Sistem Informasi Manajemen," Ris. Akunt. Dan Bisnis, vol. 1 , no. 1 , p. 267,2014

[10] K. A. Wibowo and I. B. Sulistyono, "Pemahaman Manajemen Proyek," no. 36 , pp. 2-4, 2017.

[11] G. W. Sasmito, "Penerapan Metode Waterfall Pada Desain Sistem Informasi Geografis Industri Kabupaten Tegal," J. Inform. Pengemb. IT, vol. 2, no. 1, pp. 6-12, 2017.

[12] H. O. L. Wijaya, "Implementasi Metode PIECES Pada Analisis Website Kantor Penanaman Modal Kota Lubuklinggau," vol. 3, no. September, pp. 160-164, 2018. 